\section{Simultaneous primary infection with varicella zoster and Epstein-Barr viruses}

Simultaneous infection with multiple herpes viruses is rare in healthy individuals.' We report on a 6 year old boy who, during an episode of clinically apparent infectious mononucleosis caused by Epstein-Barr virus, had a concomitant varicella zoster infection. The clinical course was uneventful except for a prolonged atypical varicelliform exanthema.

\section{Case report}

A previously healthy 6 year old boy was admitted with a two day history of slight fever and sore throat. According to his mother he had had chickenpox at the age of 2, but otherwise he had been in perfect health. During the weeks before his illness there had been a small epidemic of varicella at the day care centre which he attended.

Physical examination on admission showed generalised enlargement of the lymph nodes, especially on the anterior aspect of the neck. The tonsils were swollen with a white exudate, and a moderate hepatosplenomegaly was also found. His temperature was $37^{\circ} 7^{\circ} \mathrm{C}$. No exanthema was noted. A preliminary clinical diagnosis of infectious mononucleosis was made, and he was sent home. Two days later he was admitted to hospital because of a rise in temperature $\left(39.5^{\circ} \mathrm{C}\right)$ and inadequate fluid intake. One day before readmission a sparse generalised vesicular exanthema had developed. The lesions were about $1 \mathrm{~cm}$ in diameter and contained serous fluid. An indirect immunofluorescence test of vesicle fluid showed varicella zoster virus antigen.

Results of laboratory investigations on admission were: haemoglobin $116 \mathrm{~g} / 1$, leucocytes $15.0 \times 10^{9} / 1$ ( $20 \%$ neutrophils, $76 \%$ lymphocytes, and $4 \%$ monocytes) Atypical lymphocytes were also found. Erythrocyte sedimentation rate was $32 \mathrm{~mm}$ in the first hour, and C reactive protein concentration was $50 \mathrm{mg} / 1$ (normal value $<10 \mathrm{mg} / \mathrm{l}$ ). Serum creatinine concentration was normal $(47 \mathrm{umol} / \mathrm{l})$. Blood cultures yielded negative results, and virus isolation from the nasopharynx was also negative. The results of a Paul-Bunnel test performed two days after the onset of illness was positive (titre $1 / 160$ ). The table shows antibody titres to varicella zoster and Epstein-Barr viruses.

Serum antibody titres to Epstein-Barr and varicella zoster viruses determined by complement fixation test, enzyme linked immunoassay ELISA, and indirect immunofluorescence technique

\begin{tabular}{|c|c|c|c|c|}
\hline \multirow{2}{*}{$\begin{array}{l}\text { Days after } \\
\text { onset of } \\
\text { illness }\end{array}$} & \multicolumn{2}{|c|}{ Epstein-Barr viral capsid antibodies* } & \multicolumn{2}{|c|}{ Varicella zoster virus } \\
\hline & IgM & $\operatorname{IgG}$ & Complement fixation & IgGt \\
\hline $\begin{array}{r}2 \\
7 \\
21\end{array}$ & $\begin{array}{l}\mathrm{Neg} \\
1 / 20 \\
1 / 40\end{array}$ & $\begin{array}{r}<1 / 40 \\
1 / 80 \\
\mathrm{ND}\end{array}$ & $\begin{array}{r}<1 / 8 \\
<1 / 8 \\
>1 / 256\end{array}$ & $\begin{array}{l}<1 / 100 \\
<1 / 100 \\
\text { ND }\end{array}$ \\
\hline
\end{tabular}

$\mathrm{Neg}=$ Negative result; $\mathrm{ND}=$ No data

* Determined by indirect immunofluorescence technique.

tDetermined by enzyme linked immunoassay (ELISA).

During his stay in hospital he was given intravenous fluids for three days, but no specific treatment was required. His temperature fell to $38^{\circ} \mathrm{C}$, and he was discharged after five days. At follow up 17 days after the development of exanthema most of the vesicles were encrusted, but some new vesicles were still developing. Two months later he was in good health, all the crusts had disappeared, but some residual scarring was noted.

\section{Comment}

The lack of antibodies to varicella zoster virus in the first serum sample and the subsequent seroconversion indicate primary varicella zoster infection in our patient, despite the information given by his mother. The course of his varicella infection was prolonged, with new vesicles still appearing 17 days after the development of exanthema. The presence of IgM antibodies to Epstein-Barr viral capsid antigen, a positive result on PaulBunnel testing, and a substantial rise in titre of IgG to Epstein-Barr viral capsid antigen suggest that our patient also had a primary Epstein-Barr virus infection.

Several viruses, such as Epstein-Barr virus, are known to induce immune suppression. ${ }^{2}$ Primary Epstein-Barr virus infection is associated with depressed cell mediated immunity and disturbed monocyte and macrophage function. ${ }^{3}$ We believe that in this patient the prolonged varicella infection was the result of immune suppression caused by Epstein-Barr virus. To our knowledge this is the first reported case of simultaneous primary infection with Epstein-Barr and varicella zoster viruses.
1 Lemon SM, Hutt LM, Huang YT, Blum J, Pagano JS. Simultaneous infection with multiple herpesviruses. Am F Med 1979;66:270-6.

2 Wainberg MA, Mills EL. Mechanisms of virus-induced immune suppression. Can Med Assac 7 1985;132:1261-7.

3 Britton S. Monocyte function in infectious mononucleosis: evidence for a reversible cellular defect. J Inf Dis 1976;134:395-9.

(Accepted 9 April 1987)

Departments of Infectious Diseases and Virology, University Hospital, S-901 85 Umeå, Sweden

JAN BILLHEDEN, MD, resident physician

BENGT HILL, MD, resident physician

PER JUTO, MD, consultant virologist

BO SETTERGREN, $M D$, resident physician

BIRGER TROLLFORS, MD, associate professor

Correspondence to: Dr Jan Billheden, Department of Internal Medicine, University Hospital, S-901 85 Umeå, Sweden.

\section{Delusional depression after infectious mononucleosis}

The psychiatric complications of infectious mononucleosis include depressive illness ${ }^{12}$ and a postviral fatigue in which emotional distress is a feature. ${ }^{3}$ Delusional depression has not been reported. We report on two patients who developed delusional depression, one of whom also had encephalopathy, itself an unusual complication.

\section{Case 1}

A 21 year old man had a month long febrile illness with rash and splenomegaly a Paul-Bunnell test gave a positive result. He missed two university terms owing to lassitude and on returning to university developed increasingly depressed mood with withdrawal, early waking, and weight loss. On admission to hospital he showed severe psychomotor retardation, was incontinent of urine, and refused food and drink. He wanted to die and expressed delusions of guilt and persecution in clear consciousness. Physical examination showed no abnormality.

A Paul-Bunnell test gave a negative result, and white cell count and erythrocyte sedimentation rate were normal. Serum IgG but not IgM titres against EpsteinBarr virus capsid antigen were raised. The $T$ cell helper:suppressor ratio was normal, and serum titres of antibodies to other likely infectious agents were negative. A computed tomogram of the brain was normal.

There was no history of affective disorder. Full doses of imipramine produced no improvement, but five unilateral electroconvulsive treatments led to full recovery, sustained at six month follow up.

Case 2

A 16 year old schoolboy had a three week febrile illness with sore throat and cervical lymphadenopathy. Four months of lassitude were followed by a similar illness; heterophilic antibody testing gave a positive result. Slow recovery preceded an acute relapse of lethargy six months later. $\mathrm{He}$ developed an increasingly depressed mood with withdrawal, early waking, and weight loss. On admission to hospital he showed psychomotor retardation, was doubly incontinent, and refused fluids, requiring nasogastric feeding. He was actively suicidal and expressed delusions of guilt and contamination in clear consciousness. Physical examination showed a fourth nerve palsy and chorioretinitis.

A Monospot test gave a positive result, but white cell count and erythrocyte sedimentation rate were normal. Serum IgM and IgG titres against Epstein-Barr virus capsid antigen were raised as were Epstein-Barr virus early antigen antibody titres. Cerebrospinal fluid did not contain antibody to Epstein-Barr virus, but the protein concentration was raised at $0.9 \mathrm{~g} / \mathrm{l}$ with no white cells. Serum and cerebrospinal fluid titres of antibodies to other likely infectious agents were negative. An electroencephalogram showed bilateral slow waves; a computed tomogram of the brain was normal.

There was no history of affective disorder. Full dose clomipramine and later imipramine produced little improvement. A course of 13 unilateral electroconvulsive treatments brought about recovery, sustained at four month follow up.

\section{Comment}

In the more intensively investigated of these two cases there was clinical, electroencephalographic, and cerebrospinal fluid evidence of an encephalopathy, with serological findings consistent with a persistent infection or immune response. ${ }^{3}$ The association between infectious mononucleosis and 
the depression may have been coincidental. Evidence against this, however, is the relation between the premorbid postviral fatigue and the later onset of depression, the temporal relation between the encephalopathy and depression, and the rarity of delusional depression at this age. Although delirium is the commonest psychiatric presentation of encephalitis, delusional depression also occurs. ${ }^{5}$

A latent period between the acute infection and depression has been noted with milder depressive illnesses ${ }^{1}$ and neurological disorders. ${ }^{4}$ Delusional depression may be a late complication of infectious mononucleosis that may signal, and perhaps be mediated by, an encephalopathy.

We are grateful to Dr K Bergman and Dr M Trimble for permission to report these cases.

1 Hendler N, Leahy W. Psychiatric and neurological sequelae of infectious mononucleosis. Am $\mathcal{J}$ Psychiatry 1978;135:842-4.

2 Cadie M, Nye FJ, Storey P. Anxiety and depression after infectious mononucleosis. Br f Psychiatry 1976;128:559-61.

3 Anonymous. EBV and persistent malaise [Editorial]. Lancet 1985; $1: 1017-8$.

4 Grose C, Henle W, Henle G, Feorino PM. Primary Epstein-Barr virus infections in acute neurological diseases. N Engl f Med 1975;292:392-5.

Sobin A, Ozer MN. Mental disorders in acute encephalitis. Journal of the Mount Sinai Hospital 1966;33:73-82.

(Accepted 9 April 1987)

Department of Psychological Medicine, St Bartholomew's Hospital, London EC1A 7BE

P D WHITE, MRCP, MRCPSYCH, Mental Health Foundation training fellow

Genetics Section, Institute of Psychiatry, London SE5 8AF

$S$ W LEWIS, MPHIL, MRCPSYCH, lecturer

Correspondence to: Dr White.

\section{Unorthodox internal fixation of bone lesions in myelomatosis}

In myelomatosis there is no relation between the presence of bony lytic lesions at presentation and the length of survival. ${ }^{1}$ These lesions may be without symptoms or they may be painful, but where extensive lesions occur there is a high risk of pathological fracture or vertebral collapse. When fractures occur local radiotherapy and internal fixation are standard treatments.

\section{Case report}

An otherwise fit woman of 67 presented in July 1984 with a three week history of pain in the right shoulder, which she ascribed to vigorous housework. Tests showed a normal blood count and erythrocyte sedimentation rate $7 \mathrm{~mm}$ in firs hour). The results of biochemical investigations, including urea and electrolytes, liver function tests, plasma protein electrophoresis, serum creatinine, creatinine clearance, and serum calcium were within normal limits. Immunoglobulins were normal apart from a reduced IgA concentration of $10 \mathrm{~g} / \mathrm{l}$ (normal $12-50 \mathrm{~g} / \mathrm{l}$ ). Urine electrophoresis showed an $M$ band, which was proved to be Bence Jones protein by immunofixation. Bone marrow smears contained $10 \%$ plasma cells with many morphological abnormalities. A radiograph of the right arm showed a large lytic lesion almost replacing the upper third of the humerus. A few small lesions were noticed also in the pelvis, right scapula, and skull.

Myelomatosis was diagnosed. She was started on a standard dose of melphalan, prescribed analgesics, and encouraged to drink a lot of fluid. After four months of outpatient treatment urinary excretion of protein was reduced but she fel increasing pain in the right shoulder and weakness in the arm. Another radiograph (figure (left)) showed an extension of the lytic lesion with thin areas of cortex in the shaft of the humerus. It was considered that local radiotherapy would probably precipitate a pathological fracture, and it was decided to strengthen the humerus by injecting orthopaedic cement.

The head and upper shaft of the humerus were exposed through an anterior approach. The bone was reduced to a thick shell and the tumour had extended anteriorly into the deltoid muscle. The bone was too thin to risk curettage of the tumour; it was removed by suction from a straight metal sucker under radiological control. Radio-opaque methyl methacrylate was injected under radiological control by means of a "cement gun" that had disposable plastic containers. Two containers of cement were needed to fill the humerus but there was no systemic reaction to the setting of this unusually large amount of cement. A radiograph taken after the operation showed a solid column of cement filling (figure (right)). She was discharged home three days later, and the wound healed uneventfully. The arm remained functional for 18 months apart from some limitation of movement at the shoulder joint, and she continued running her home. During this time radiographs showed no changes and radiotherapy was not necessary. In August 1986 she was admitted with a collapsed T8 vertebra and incipient paraplegia; this progressive paraplegia confined her to a wheelchair. She died of complications due to chemotherapy.

\section{Comment}

Methyl methacrylate is extensively used in hip and other joint replacements. ${ }^{23}$ Toxic effects include allergic reactions and damage to the normal function of neutrophils. ${ }^{4}$ There are also reports of cardiorespiratory side effects due to monomer diffusing out of the polymerising cement mass. In our patient the heat generated by the setting cement and its toxic effect on cells may have helped suppress plasma cells and osteoclast activity. ${ }^{5}$

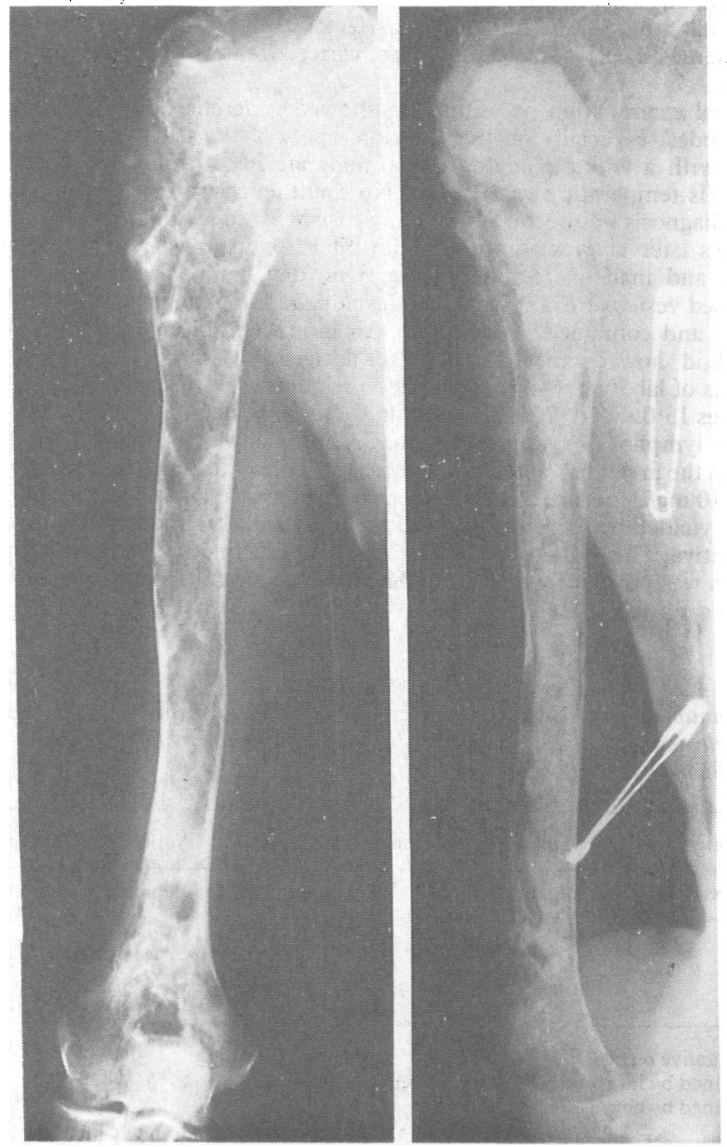

Radiographs of humerus (left) before and (right) after surgery

Our satisfactory results may have been because the general condition of the patient was excellent and the only large bony lesions were in the right humerus. We are not aware that this method of internal fixation has been used before in myelomatosis; it may be applicable to lytic lesions in other sites.

1 Buckman R, Cuzick J, Galton DAG. Long term survival in myelomatosis, Br f Haematol 1982;52:589-99.

2 Scales JT. Bone and joint replacement for the preservation of limbs. $\mathrm{Br} \mathrm{J} \mathrm{Hosp} \mathrm{Med}$ 1983;30:220-32.

3 Nixon J. Non-cemented hip prosthesis. BrMed f 1985;290:1680-2.

4 Petty W. The effect of methyl methacrylate on bacterial phagocytosis and killing of human polymorphonuclear leucocytes. Bone foint Surg [Am] 1978;60:2-7.

5 Durie BGM, Schmon SE, Mundy GR. Relation of osteoclast activating factor production to extent of bone disease in multiple myeloma. Brf Haematol 1981;47:21-30.

(Accepted 15 April 1987)

Department of Haematology and Orthopaedic Surgery, Hillingdon Hospital, Uxbridge, Middlesex UB8 3NN

ALENA KUBIE, MD, CHB, clinical assistant in haematology

P I BUSFIELD, FRCS, consultant orthopaedic surgeon

R P BRITT, MB, FRCPATH, consultant haematologist

Correspondence to: Dr Kubie. 